\title{
Law Enforcement Against Liquor Distribution by Police in The District of Demak
}

\section{Misbakhul Munir $^{1}$ and Sri Endah Wahyuningsih ${ }^{2}$}

Abstract. Issues examined in this study were (1) Implementation of law enforcement against liquor by the Police Demak. (2) Obstacles encountered. (3) How the solutions do about it. The purpose of this study was to understand, describe, analyze and assess the implementation of enforcement by the Police in combating liquor Demak. The method used is Juridical Sociological with specification of descriptive analysis, the data used are primary data and secondary data so that the data collection method used is qualitative analysis. (1). Implementation of Law Enforcement by Police in combating liquor Demak carried out by (a) Preventive measures, namely the dissemination and raids (b) repressive actions, namely investigation, investigation, prosecution and trial. (2). Barriers Police Demak in law enforcement in combating the circulation of liquor (a) factor is the law that is not yet the enactment of a special law regulating the circulation of liquor (b) Factors law enforcement, namely the limited human resources (c) Factors of facilities (d) community factors, namely the lack of legal awareness (e) Cultural factors of society violates the cultural values of society. (3) Efforts by the Police Demak to overcome the obstacles in the fight against the circulation of liquor (a) Factors law (b) Improve the quality of Human Resources (c) Adding equipment and funds (d) Conducting socialization (e) To promote cooperation between agencies Related in Demak district.

Keywords: Law Enforcement, Police, Liquors.

\section{Introduction}

Indonesia is a democratic law based on Pancasila and the 1945 Constitution, uphold the law, and justice under the law should be implemented every citizen, the organizer of the State, public institutions and state institutions, the legal system or the system of norms that apply in Indonesia. ${ }^{3}$

Crime can not be separated from the presence of problem in society law violation or crime is the responsibility of every society, because the crime was as old as the history of people's lives, also evolved from construction of society itself. Crime will lead to social unrest and a harmful disease, it is logical for people to show its attitude towards all forms of crime.

\footnotetext{
${ }^{1}$ Student of Masters (S2) of Law Faculty of Law Unissula Semarang and Police members email: misbakhulmunir427@gmail.com

${ }^{2}$ Lecturer of Faculty of Law UNISSULA Semarang

${ }^{3}$ Ilham Bisri 2011 the Indonesian Legal System PT. RajaGrafindo Persada Jakarta p. 5
} 
Other crimes are no less terrible and a negative impact on society and the environment is the circulation of alcoholic beverages is often called liquor, not only because of the influence of promiscuity but also the negative impact of globalization which has eroded the nation's culture and tend to follow the western culture does not know ethics such as promiscuity, alcoholism.

Along with the advancement of science (Science and Technology) human behavior in society and state life even more complex. Tinggkah such behavior if the terms of the law of course there are behaviors that are categorized in accordance with the norms in general and legal norms in particular and there are behaviors that do not fit the norm. This behavior can be called as a diversion to the norm that has been agreed, this has led to the disruption of order and peace of human life. ${ }^{4}$

One issue of particular concern and should receive serious attention from the government is the problem of liquor consumed by the public, consume alcoholic beverages excessive very big influence on the attitudes and behaviors that lead to deviation, as well as speeding on the highway that can disturb the order traffic, making a mess and noise and disturbing the peace of other people. ${ }^{5}$

Liquor consumed by the elderly, youth and even children have started to try to drink it because of curiosity to know as well as environmental factors. Many victims as a result of this drink, the drink is often used as a beverage for custom events as well as a drink to have fun because this drink does cause addictive effects of alcohol when consumed in excess can cause disease. ${ }^{6}$

Downing liquor is usually done, and the impact is so harmful than any other crime, especially trafficking of liquor more incentive that is illegal, facilitate the public to get it. The circulation of the liquor itself has been included in an offense, and as a result of the liquor would generate other crimes such as murder, theft, robbery and others that are not recognized stems from consuming liquor.

Alcoholic liquor is one type of Naza (narcotics, alcohol and addictive substances) in the form of liquor containing alcohol, meaning that these substances can lead to addiction (addiction) is addictive and dependency (dependency). Can cause organic mental disorders, ie disorders in the function of thinking, feeling, and behaving, organic mental disorders is due directly to the neuro-transmitter alcohol nerve cells of the central (brain). ${ }^{7}$

Circulation of liquor can be found dipenjualan, in the homes, kiosks, or when there is a public entertainment events. With so many sellers of liquor is causing the expansion of liquor for consumers to get it very easy to reach teenagers.

The Code of Penal (Penal Code) has been set up on the crime of liquor (wine), namely Article 300, Article 492, Article 536, Article 538 and Article 539 of the Criminal

\footnotetext{
${ }^{4}$ Bambang Waluyo 2008 Crime and Punishment Sinar Grafika Jakarta 2008 p. 1

${ }^{5}$ Soejono Dirjosisworo 1984 Alkoholisme Paparan Hukum dan Kriminolgi Remaja Karya Bandung p. 111

${ }^{6}$ Hartati Nurwijaya 2009. Bahaya Alkohol dan Cara Mencegah Kecanduan. PT. Elex Media Komputindo. Jakarta p. 1

${ }^{7}$ Dadang Hawari Penyalahgunaan \& Ketergantungan NAZA (Narkotika Alkohol \& Zat Adiktif). Balai Penerbit FKUI Jakarta 2005 p. 52
} 
Code. ${ }^{8}$ This regulation is built on the assumption that by not sell alcoholic beverages in the mini market which complicates children's access to alcohol can protect the morals and culture of the community and keep children away from the negative effects of alcohol. These regulations cause problems precisely adulterated alcohol consumption, due to the difficulty to reach on mini market, young children and even society in general turn to alcohol adulterated. This will increase the risk of poisoning or even death.

To create a litigious society and create kondisifitas region, require a serious form of treatment from law enforcement to maintain security and order in society, the role of the community is also very important because the development of the law can not work properly if the public and law enforcement is not in line

Police aim to protect the public, trying to carry out duties in accordance with the provisions stipulated in the Act so that the implementation of the tasks of the police are not distorted and people are not always blame the police officers if there are things in nature are beyond the functions and authority of the police itself.

Based on the description of the above outlined the issues to be discussed in the paper are: How can law enforcement against the circulation of liquor by the Police in Demak?; A limiting factor in the circulation of liquor law enforcement by the Police in Demak?; and How does the solution to the obstacles faced in enforcing the law against the circulation of liquor by the Police in Demak?

\section{Result And Discussion}

\subsection{Law Enforcement}

Law enforcement is a process or an attempt to realize the concepts, ideas were very abstract legal purposes. Appropriate legal purpose or ideals of law according to moral values such as justice and truth. Those values must be able to be realized in the real reality that the existence of law is recognized when the moral values contained in the law can be better implemented. ${ }^{9}$

Law enforcement as a process is essentially a board of directors concerning the application to make decisions are not strictly regulated by law but it has many elements of personal assessment, conceptual essence and meaning of law enforcement lies in harmonizing relations activities outlined values or rule steady as a translation of the value of the final stage, to create, give birth to social life and maintaining peace. ${ }^{10}$

Law enforcement is a circuit that is done by law enforcers, both prevention and enforcement measures in implementing the provisions in force in order to create an

\footnotetext{
${ }^{8}$ R. R. Susilo Kitab Undang-Undang Hukum Pidana (KUHP) Pelita : Bogor p. 160-172

${ }^{9}$ Satjipto Raharjo Penegakan Hukum Suatu Tinjauan Sosiologis Cetakan Kesatu Genta Publisihing Yogyakarta 2009 p. vii

${ }^{10}$ Soejono Soekanto 2012 Faktor-faktor yang Mempengaruhi Penegakan Hukum PT Rajagrafindo Jakarta p. 5.
} 
atmosphere of security, peace and order for the sake of legal certainty together. ${ }^{11} \mathrm{~A}$ law enforcement problem is a problem that is not simple, because of the complexity of the legal system itself, but the complexity of the relationships between the legal system to the social system, economy, and culture.

According to Abdul Hakim that law enforcement carried out in two (2) ways:

- Preventive action. Actions taken if possible and still their awareness to obey the law.

- Repressive measures.

Repressive measures are measures to be taken if prevensif measures are not effective, so that the people carrying out the law, although with compulsion.

The theory of the factors that affect law enforcement by Soerjono Soekanto:

- Legal Factors

The practice of the administration of justice in the field sometimes a conflict between legal certainty and justice, this is caused by a conception of justice is a formula that is abstract, whereas legal certainty is a procedure that has been determined normatively.

- Factors Law Enforcement

The function of law, mentality or personality law enforcement officers play an important role, if regulation is already good, but the quality is less good officers, there is a problem. Therefore, one of the keys to success in law enforcement is law enforcement mentality or personality.

- Factors Facilities and Support Facilities

Factors facilities or support facilities include the software and the hardware, software one is the education received by the police today tend to the practical matters of conventional, so that in many cases the police have problems in goal.

- factors Society Law enforcement from public and aims to achieve peace in the community. Each community or group has a more or less legal awareness, the question that arises is tarap legal compliance, the compliance is high, medium or less.

- Cultural factors

Based on the concept of everyday culture, people so often talk about culture. Culture by Soejono Soekanto, has a very big function for man and society, which is arranged so that people can understand how it should act, act, and determine their attitude when dealing with others. Thus the culture is a fundamental line of conduct set rules about what to do and what is forbidden.

\subsection{Police}

Indonesian National Police according to Act No. 2 of 2002 has the duty and authority, among others:

\footnotetext{
${ }^{11}$ Singgih Warsito Kurniawan Implementasi Restoratif Justice pada Penegakan Hukum Tindak Pidana Pencabulan Anak di Wilayah Direktorat Reserse Kriminal Umum Kepolisian Daerah Riau JOM Fakultas Hukum Vol. 1 No. 1 Universitas Riau Pekanbaru Februari 2015 p. 6.
} 
- Coordination, supervision and technical guidance to the special police, investigator of civil servants, and other forms of spontaneous surveillance [Article 14 paragraph (1) f];

- Conducting the investigation against all offenses, according to the criminal procedure law and legislation [Article 14 paragraph (1) letter g];

- Arrest, detention, search, and seizure [Article 14 paragraph (1) letter a];

- Prohibit any person leaving or entering the crime scene for the purpose of investigation [Article 16 paragraph (1) letter b];

- Carrying and exposes people to an investigator in the framework of the investigation [Article 16 (1) c];

- Ordered to stop the suspect and asking and checking personal identification [Article 16 paragraph (1) letter d];

- Conducting the investigation termination [Article 16 (1) h];

- Submit a case file to the public prosecutor [Article 16 paragraph (1) letter i];

- Submit a request directly to the competent immigration officials at the immigration check in urgent circumstances or to prevent or counteract sudden persons suspected of committing criminal offenses [Article 16 paragraph (1) letter j];

- Provide guidance and assistance to investigators investigation of civil servants as well as receiving the investigation results investigator of civil servants to be submitted to the public prosecutor [Article 16 paragraph (1) letter k];

- Other actions held responsible according to the law [Article 16 paragraph (1) item 1].

Police make an effort acts as duties and authority granted by the legislation. Police in law enforcement efforts to combat liquor continues to do, given the negative impact of its circulation in the community. It received the full support of the community.

Police status as a component of the criminal justice system have been clearly involved in the legislation in force at present (either in the Criminal Code and in Act No. 2 of 2002). le as the investigator and the investigator, conduct investigations and examinations.

This investigation actions carried out by investigators, the Indonesian National Police officer who is authorized by the Act (Criminal Code) to conduct an investigation. The authority of investigation, among others, namely: ${ }^{12}$

- Receive reports or complaints from anyone about the crime;

- Finding information and evidence;

- Says stop a suspect and asking and checking personal identification;

- Other actions held legally responsible.

\subsection{Liquor}

Circulation liquor alcohol content, known as the liquor is rife in several cities in Indonesia. According to Article 1 paragraph 2 of Regulation of the Minister of Health of the Republic of Indonesia Number: 86 / Menkes / Per / IV / 77 of the Liquor, which

\footnotetext{
${ }^{12}$ Mahrus Ali Hukum Pidana Korupsi di Indonesia Cetakan Pertama UII Press Yogyakarta 2011 p. 164.
} 
meant liquor is: "All types of alcoholic beverages, but not drugs, that includes liquor class A, liquor class B, class C liquor ".

Sales of liquor in public places illegal merupkan. Simply, to obtain illegal liquor brings disastrous consequences, especially for the next generation. Great curiosity and eventually try, eventually can affect the behavior of children who consume liquor.

Liquor-made by mixing the ingredients that should not be mixed with liquor, such as sports drinks, milk, soft drinks, pharmaceuticals, and others. Mix booze with these materials may cause side effects to cause death to those who consume them.

Consuming alcohol effects can be experienced by those who consume it at the time after drinking it and the effects in the long term. Liquor they contain hazardous materials that can not be digested by the body and are very dangerous and can damage body tissue.

People who consume liquor will be less able to control himself. If you've often liquor, then that person will become dependent and will perform a variety of ways to get liquor, including committing a criminal act of extortion, theft, and so on.

The effects of alcohol consumption are due to lack of awareness of themselves to act or act, so that people who consume liquor or liquor are not aware when they committed a crime. Of course the actions performed unconsciously they can harm or harm to others.

As noted by Nuegroho Djajoesman that result from drinking alcohol will suppress the central control of a person concerned is a bold and aggressive, and the arena bravery and aggressiveness and depressed restraint that someone did disruption of security and public order (internal security), either in the form of violation of norms -norma and moral attitude even some with criminal and criminal. ${ }^{13}$

The criminal act of liquor with a variety of effects and the negative effects of the sting be disturbing public order and safety, teen terlabih again very easily get liquor into a crime that can destroy the next generation.

\section{Closing}

\subsection{Conclusion}

- The enforcement by the Police in combating liquor Demak done: (a) preventive measures, namely the dissemination and take actions by means of patrols and raids to increase public awareness; or (b) repressive actions, namely conduct investigations and inquiries which then proceed to the stage of prosecution and trial in the District Court Demak;

- Barriers Police Demak in law enforcement in combating liquor oplosan of: (a) legal factors, namely the lack of legislation governing the crime of liquor in particular so that they use the Code of Criminal Law and regulated in District Regulation Demak No. 2, 2015. Its only a violation; (A) law enforcement factors, namely the lack of personnel; (B) the means or facility of factors, namely the lack of means or facilities such as vehicles, communication tools are proportionate and adequate funds; (C)

\footnotetext{
${ }^{13}$ Noegroho Djajoesman Mari Bersatu Memberantas Bahaya Penyalahgunaan Narkoba Kepolisian Negara Republik Indonesia Jakarta,1999 p. 9.
} 
community factors, namely the lack of legal awareness masyaraka (d) cultural factors, such as the people do bad deeds that violate cultural values of society;

- The efforts made by the Police Demak to overcome the obstacles in combating liquor: (a) legal factors, namely to ensure legal certainty; (B) adding personnel and improve the quality of human resources; (C) adding the necessary equipment. (D) held socialization; and (e) cooperating with Demak District Government to restore the cultural values of society.

\subsection{Suggestion}

- Necessary laws governing criminal offenses liquor specifically remember the danger to society in general and youth in particular;

- Need for socialization in schools and higher education on the dangers of liquor;

- Provide rewards for members of the public who reported the circulation of illegal liquor and liquor at the Police.

\section{Bibliography}

[1] Bambang Waluyo 2008 Pidana dan Pemidanaan Sinar Grafika Jakarta.

[2] Dadang Hawari 2005 Penyalahgunaan \& Ketergantungan NAZA (Narkotik Alkohol \& Zat Adiktif) Balai Penerbit FKUI Jakarta.

[3] Hartati Nurwijaya 2009 Bahaya Alkohol dan Cara Mencegah Kecanduannya. PT. Elex Media Komputindo Jakarta.

[4] Ilhami Bisri 2011 Sistem Hukum Pidana di Indonesia PT. Rajagrafindo Persada Jakarta.

[5] Mahrus Ali 2011 Hukum Pidana Korupsi di Indonesia Cetakan Pertama Yogyakarta.

[6] Nawawi Arif Barda. 1984. Sari Kuliah Hukum Pidana II. Semarang: Fakultas Hukum Undip.

[7] Noegroho Djajoesman Mari Bersatu Memberantas Bahaya Penyalahgunaan Narkoba Kepolisian Negara Republik Indonesia Jakarta 1999

[8] R. Susilo Kitab Undang Undang Hukum Pidana (KUHP) Pelita : Bogor.

[9] Satjipto Raharjo. 2009 Penegakan Hukum Suatu Tinjauan Sosiologis Cetakan Kesatu Genta Publisihing Yogyakarta.

[10] Singgih Warsito Kurniawan Implementasi Restoratif Justice Pada Penegakan Hukum Tindak Pidana Pencabulan Anak di Wilayah Direktorat Reserse Kriminal Umum Kepolisian Daerah Riau JOM Fakultas Hukum Vol. 1 No. 1 Universitas Riau Pekanbaru 2015

[11] Soejono Soekanto 2012 Faktor-faktor yang Mempengaruhi Penegakan Hukum PT Rajagrafindo Jakarta.

[12] Soejono Dirjosiswoyo 1984 Alkoholisme Paparan Hukum dan Kriminologi Remaja Karya Bandung.

[13] The Code of Penal (Penal Code)

[14] Act No. 2002 on the State Police of the Republic of Indonesia. 
[15] Presidential Regulation No. 74 of 2013 on Control and Supervision of Alcoholic Beverages.

[16] Indonesian Trade Minister Regulation No. 20 / M-DAG / PER / 4/2015 on Control Of Procurement Distribution and Sale of Liquor.

[17] Demak Kapupaten Regional Regulation No. 2 of 2015 on Disease Society (dark). 